\title{
Public Finance Expenditure And Awarding Work To External Contractors - Case Of Slovenia
}

\author{
Stanka Setnikar-Cankar, Ph.D., University of Ljubljana, Slovenia \\ Janko Seljak, Ph.D., University of Ljubljana, Slovenia \\ Veronika Petkovšek, University of Ljubljana, Slovenia
}

\begin{abstract}
The research project "Awarding Work to External Contractors" studied the practice of implementing public contracts in a significant selection of Slovenian local government bodies. Public procurement has become a permanent accompaniment to the business of central and local government and other public law persons with the private sector, and now goes beyond Slovenia's borders. The public procurement system aims at dynamism, with the possibility of a rapid response to the needs of those using public funds. The principles of public procurement and its legal basis mean the system is rigid and complex, by its nature.
\end{abstract}

Keywords: public expenditure; public procurement; local government; public tender procedure

\section{INTRODUCTION}

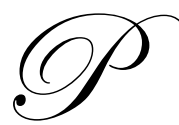

ublic procurement is a field in which central and local government and the economy meet. Public procurement represents a significant proportion of national budget expenditure and of GDP. Recently, public procurement has increasingly extended beyond local and even national borders. Public procurement is a part of the public sector's purchasing function that distinguishes it from the private sector. The public sector generally spends budget funds, where the aim of operations is not to maximise or generate profits, but to satisfy the needs of the community and individuals that cannot be met via market mechanisms. The central government therefore attempts to use legal regulation to improve weaknesses in the public procurement system that only come to light in practice.

Public procurement covers economic, financial, social, political and legal aspects (Mužina \& Vesel, 2007, p. 15). Legally, public procurements are defined as a group of legal actions, with which the central government or state, on the basis of financial relationships, purchases goods, awards contracts for services and construction work, in line with prescribed procedure (Kranjc, 2006a, p. 1437).

Public procurement demands a detailed legal arrangement due to the significant pressure from potential tenderers to create rules enabling equal and fair access to public procurements. . States with prescribed procedures regulating budget spending achieve the rationalisation of operations create procedural transparency, economy and equality of businesses in dealings with budget spending units.

\section{PUBLIC PROCUREMENT AND LEGAL ORGANISATION}

Through public procurement most western European states have carried out a partial privatisation of the public sector (Setnikar Cankar et. al., 2008). Public procurement is used to pursue various objectives. These include facilitating competition in the goods and service market, preventing corruption and increasing public trust in the management of public funds, rationalising public spending, and realising economic policy (Planet GV, 2009). 
Public contracts are one of the most important instruments in establishing competition on the market. Public contracting has a favourable effect on the economy and sets a standard for the quality of services, goods and construction. This undoubtedly allows contracting authorities to offer more efficient and effective work. This strengthens the national economy, and increased competitiveness on the domestic market can have a positive impact on the expansion of domestic businesses into foreign markets.

Slovenia gained its first Public Procurement Act in 1997 (Official Gazette of the Republic of Slovenia, No 24/97). Before this act came into force, two regulations governed the field: the Order on the Conditions and Methods of a Public Tender to Procure Works financed from the Budget of the Republic of Slovenia (OGRS, No 24/92) and the Order on the Procedure to Implement a Tender to Award Public Contracts with Related Amendments (OGRS, Nos 28/93 and 19/94). The amended Public Procurement Act (OGRS, Nos 39/00 to 2/04, official Slovenian abbreviation: ZJN-1) was adopted on 25 April 2000, and entered into force on 13 November of the same year (Gregorič, 2008, p. 36).

After the entry into force of the act it became clear that some provisions represented a legal and actual obstacle to implementing public procurement procedures. The act included concepts that were unknown to domestic law, and the act was inconsistent in the application of these concepts with some provisions being vague or significantly lacking in clarity. The need for an amended act soon became apparent (Mužina, Pirnat, 2007 p. 17).

A new amended Public Procurement Act (ZJN-2) has been in force since early 2007, which introduced a number of innovations to public procurement practice. The Act on Public Procurement in Water Management, Energy, Transport and Postal Services was adopted in parallel, with both acts entering into force on 7 January 2007. The ZJN-2 applies to the public procurement of goods, services and construction, by 'traditional' public contracting authorities (central government bodies, local communities, public institutions, etc.). The second act applies to contracting authorities operating in the infrastructure sectors: energy, water supply, transport and postal services.

\section{PRESENTATION THE RESEARCH PROJECT}

Public procurement has therefore become an "essential accompaniment to central government business with the private sector" (Šoltes, 2007, p. 558).

The survey entitled "Awarding Work to External Contractors" was carried out between November 2008 and January 2009. The population comprised municipalities which had over 8000 inhabitants on 30 June 2007. This included 65 municipalities, which together had $73.5 \%$ of the total Slovenian population. Forty-five municipalities agreed to cooperate. This represents $21 \%$ of all municipalities, $50.4 \%$ of total inhabitants and $49.9 \%$ of total municipal expenditure in Slovenia in 2007.

The survey was carried out from 10 January 2009 to 28 February 2009 with assistance from postgraduate students on the master's programme in Public Administration. The survey format depended on an agreement between the surveyors and respondents: as a personal survey or via email. All financial data are presented in euros. The 2005 and 2006 data provided by the municipalities in tolars were converted at the rate of 239.64 tolars $=1$ euro.

Table 1: Inhabitants, revenues and expenditure in Slovenian municipalities in 2007

\begin{tabular}{|l|c|c|c|}
\hline \multicolumn{1}{|c|}{ Municipality group } & $\begin{array}{c}\text { Inhabitants on } \\
\mathbf{3 0 . 6 . 2 0 0 7}\end{array}$ & $\begin{array}{c}\mathbf{2 0 0 7} \text { expenditure } \\
\text { (euros) }\end{array}$ & $\begin{array}{c}\text { 2007 revenues } \\
\text { (euros) }\end{array}$ \\
\hline Total - Slovenia & $2,019,406$ & $1,722,593,084$ & $1,710,495,356$ \\
\hline All municipalities with over 8,000 inhabitants & $1,484,655$ & $1,267,487,728$ & $1,235,354,832$ \\
\hline Municipalities participating in the survey & $1,016,233$ & $859,653,608$ & $846,436,017$ \\
\hline
\end{tabular}

Source: Ministry of Finance, 2009

Particular focus was given to urban municipalities. The survey included 9 of the 11 urban municipalities. The urban municipalities represented $34.4 \%$ of the total Slovenian population, and those participating in the survey represented $26.4 \%$. 


\section{ORGANISATION AND IMPLEMENTATION OF PUBLIC PROCUREMENT}

Major changes took place over the period in the observed population and the observed variables. The currency changed (from Slovenian tolar to the euro), and on 1 January 2007 new municipalities were established. Data comparability between 2005-2006 and 2007-2008 is therefore only possible between municipalities that did not change (39 observed municipalities). On 1 January 2007 the following municipalities were reduced in size: Bled, Gornja Radgona, Nova Gorica, Novo Mesto, Ormož and Vrhnika. The larger municipalities were divided into two smaller ones on 1 January 2007, one of which usually had fewer than 8000 inhabitants. The survey did not collect data on these municipalities, and aggregation cannot therefore provide comparative data.

Table 2: Number and value of public contracts in observed municipalities 2005 - 2007 (\#\#)

\begin{tabular}{|l|c|c|c|c|c|c|}
\hline \multirow{2}{*}{} & \multicolumn{5}{|c|}{ Municipality type } \\
\cline { 2 - 6 } & Urban municipalities & Other municipalities & \multicolumn{2}{c|}{ Total } \\
\cline { 2 - 6 } & Arit. mean & No & Arit. mean & No & Arit. mean & No \\
\hline E2005 - No of PPs - total (low and high) $(*)$ & 765.3 & 8 & 151.1 & 31 & 277.1 & 39 \\
\hline E2006 - No of PPs - total (low and high) $(*)$ & 863.0 & 8 & 191.5 & 32 & 325.8 & 40 \\
\hline E2007 - No of PPs - total (low and high) $(*)$ & 737.2 & 9 & 174.7 & 30 & 304.5 & 39 \\
\hline E2005 - Value of PPs $(€)$ - total (low and high) $\left(^{*}\right)$ & $8,115,053$ & 8 & $1,757,776$ & 25 & $3,298,934$ & 33 \\
\hline E2006 - Value of PPs $(€)$ - total (low and high) $(*)$ & $11,186,607$ & 8 & $2,300,314$ & 29 & $4,221,675$ & 37 \\
\hline E2007 - Value of PPs $(€)-$ total (low and high) $(*)$ & $10,021,370$ & 9 & $2,420,767$ & 29 & $4,220,910$ & 38 \\
\hline
\end{tabular}

(*) differences are statistically significant at $\mathrm{p}<0.05$

(\#\#) 2008 data was only submitted by 5 urban municipalities and 22 other municipalities. Since the variation among municipalities is high and comparability therefore contestable, it was decided to exclude 2008 data from this comparison.

Responsible persons in municipalities responded to questions about unresolved issues in the organisation and implementation of public procurement by mentioning personnel problems.

Table 3: Organisation of public procurement

\begin{tabular}{|l|c|c|c|c|}
\hline \multirow{2}{*}{$\begin{array}{c}\text { Does the body have an organised services, department, } \\
\text { section ... for public procurement? }\end{array}$} & \multicolumn{2}{|c|}{ Municipality type } & \multicolumn{2}{c|}{ Total } \\
\cline { 2 - 5 } & yes & 3 & 3 & 6 \\
\hline & no & 6 & 32 & 38 \\
\hline Total & & 9 & 35 & 44 \\
\hline
\end{tabular}

There was a statistically significant difference between urban and other municipalities on this issue ( $\chi^{2}$ $=3.7, \mathrm{p}<0.05$ ). Despite this form of organisation, $13.5 \%$ of the 44 observed municipalities did not have oversight in place, to prevent public contracts becoming broken down into smaller contracts to avoid the stricter provisions. None of the six municipalities in this situation was an urban municipality. Only $13 \%$ of the 44 municipalities that responded to this question had an organised public procurement service. About one third of the urban municipalities had such a service.

Table 4: Types of service which municipalities award to outside contractors in public procurement procedures

\begin{tabular}{|l|c|c|c|c|c|c|}
\hline \multirow{2}{*}{ Service type } & \multicolumn{6}{c|}{ Municipality type } \\
\cline { 2 - 7 } & Urban municipalities & \multicolumn{2}{c|}{ Other municipalities } & \multicolumn{2}{c|}{ Total } \\
\cline { 2 - 7 } & Arit. mean & No & Arit. mean & No & Arit. mean & No \\
\hline Legal services & 2.88 & 8 & 2.81 & 36 & 2.82 & 44 \\
\hline Information services & 2.63 & 8 & 2.31 & 35 & 2.37 & 43 \\
\hline Security services (*) & 1.25 & 8 & 2.44 & 34 & 2.21 & 42 \\
\hline Cleaning services & 1.25 & 8 & 2.11 & 35 & 1.95 & 43 \\
\hline Vehicle fleet maintenance services & 2.63 & 8 & 2.49 & 35 & 2.51 & 43 \\
\hline Economic consultancy services & 3.25 & 8 & 3.03 & 35 & 3.07 & 43 \\
\hline
\end{tabular}

Survey respondents could choose on a scale of 1 (always) to 4 (never)

(*) differences are statistically significant at $\mathrm{p}<0.05$ 
First place in the breakdown by value for both groups was for public contracts in construction, while services predominated in the breakdown by number. The services most frequently awarded to external contractors in the observed municipalities were cleaning services, followed by security services, which were awarded much more frequently by urban municipalities (statistically significant differences). The least frequently awarded services were legal services and economic consultancy services.

\section{AWARDING PUBLIC CONTRACTS}

Public procurement can be divided into two groups: low value public procurements, and high value public procurements. A year-on-year comparison of the total of high-value and low-value public procurements indicates that they increased significantly in number from 2005 to 2006, while they fell in 2007. A significant growth in value can be seen in 2005 and 2006, after which total value remained at the same level. In the urban municipalities the total value even fell. However, it should once more be emphasised that the number of municipalities reporting the number and value of public procurements differs, with some municipalities even being reduced in size on 1 January 2007, due to new local legislation.

Table 5: Value of public procurements as proportion of 2007 municipality expenditure

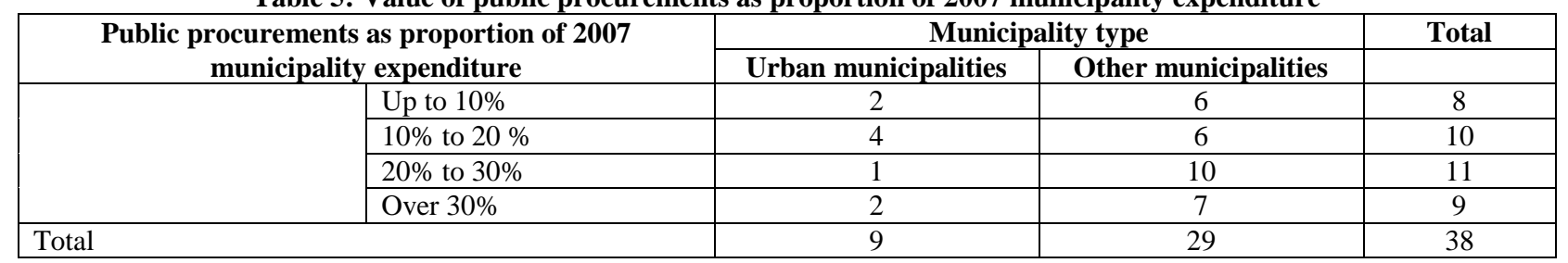

The total value of public procurements was compared with 2007 municipality expenditures. The comparison reveals large differences between municipalities, which probably reflects the periodic nature of investment cycles. In almost half of municipalities, over $20 \%$ of all expenditure was allocated to public procurements, and below $20 \%$ in half of them. inhabitant.

A similar breakdown is obtained if municipalities are compared in terms of public procurement value per

Table 6: Value of public procurements per municipality inhabitant in 2007

\begin{tabular}{|l|l|c|c|c|}
\hline \multirow{2}{*}{ Value of public procurement per inhabitant in 2007 } & \multicolumn{2}{|c|}{ Municipality type } & Total \\
\cline { 2 - 5 } & Urban municipalities & Other municipalities & \\
\hline \multirow{5}{*}{} & Under EUR 100 & 2 & 8 & 10 \\
\cline { 2 - 5 } & EUR 100 to EUR 200 & 3 & 10 & 13 \\
\cline { 2 - 5 } & EUR 200 to EUR 300 & 3 & 4 & 10 \\
\cline { 2 - 5 } & Over 400 EUR & 1 & 5 & 38 \\
\hline Total & 9 & 29 & 3 \\
\hline
\end{tabular}

In $60 \%$ of municipalities less than EUR 200 per inhabitant was allocated, but more than EUR 200 in $40 \%$ of municipalities. However, there is almost no difference between the urban municipalities and other municipalities.

\section{PUBLIC TENDER PROCEDURES}

New procurement procedures were introduced such as a dynamic system, electronic auction, and competitive dialogue. The changes to legislation (the amended Public Procurement Act, ZJN-2) were assessed positively by municipalities. As many as $72 \%$ of respondents consider that the legislature acted correctly by including the possibility of eliminating accounting errors in the provisions of the ZJN-2. The ZJN-2 also permits the supplementing of tenders that are found to be only formally incomplete. This possibility offers an advantage to both 
contracting authorities and tenderers in the opinion of $73 \%$ of respondents, while $27 \%$ considered that it offered more advantages to tenderers than to contracting authorities. According to the $\mathrm{ZJN}-2$, for public procurements worth less than EUR 10,000 for goods and services and EUR 20,000 for construction (i.e. low-value public procurement), municipalities are only required to keep records of their award.

In $34 \%$ of municipalities, there was no internal act in place defining rules of conduct for low-value public procurements, though only one of these is an urban municipality. In $20.5 \%$ of the 44 observed municipalities, no market research was carried out before awarding public contracts of this kind.

The respondents considered that negotiations frequently allowed more favourable tenders to be obtained. Despite this, negotiations were rarely used for high-value contracts in the observed municipalities. The forms of negotiations used in the observed municipalities in 2008 were, most commonly, negotiations in meetings (separately with each tenderer), with written negotiations in second place.

The most frequently used public procurement procedures in the observed municipalities for both types of high-value public procurement, i.e. for goods and services (EUR 40,000 to EUR 133,000) and construction (EUR 80,000 to EUR 5,150,000), were open procedures and invitations to tender after prior announcement.

Table 7: Realisation of contracts

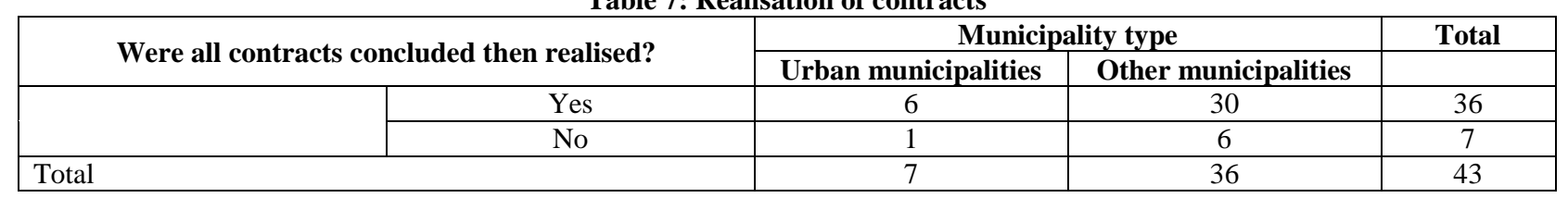

In $84 \%$ of the 43 municipalities that responded, contracts concluded were then realised. Only $7 \%$ (3 municipalities) filed claims due to failure to realise a contract between 2005 and 2008. None of these was an urban municipality. The respondents in observed units assessed that the greatest risk to realisation of contracts lie in failure to meet deadlines ( $36 \%$ of all statements), and in the quality of expert oversight ( $25 \%$ of all statements).

The most frequently used instrument of surety in the observed municipalities is a bank guarantee (in $88 \%$ of 43 municipalities). Contractual penalties are most frequently included in public procurement contracts in the field of construction, and least frequently in the field of goods.

Table 8: Measures to improve the realisation of public procurements

\begin{tabular}{|l|c|c|c|}
\hline \multirow{2}{*}{$\begin{array}{c}\text { What have you improved in your operations or which } \\
\text { measures have you passed based on experience of public } \\
\text { procurement realisation? }\end{array}$} & \multicolumn{2}{c|}{ Municipality type } \\
\cline { 2 - 4 } & Urban municipalities & Other municipalities \\
\hline Create better records & 8 & 34 & 42 \\
\hline Great staff specialisation (recruitment, training) & 5 & 26 & 31 \\
\hline Strengthening internal controls & 4 & 22 & 26 \\
\hline Greater involvement of other specialist staff in PP procedures & 6 & 14 & 20 \\
\hline Better quality planning & 4 & 13 & 17 \\
\hline Better quality tender dossier preparation & 3 & 9 & 14 \\
\hline Starting procedure on time & 4 & 9 & 13 \\
\hline Improving preparation of contracts & 3 & 1 & 12 \\
\hline Other & 0 & 139 & 1 \\
\hline Total & 37 & & 176 \\
\hline
\end{tabular}


In response to the question of which types of public procurement most frequently include annexes to contracts, respondents placed construction in first place in $86 \%$ of cases. The second most frequent use of annexes to contracts was for services, and in third place, goods, which was placed first by just $5 \%$ of observed municipalities (in 2 municipalities).

In response to the question of what improvements in operations have been made or which measures have been adopted based on experience of public procurement, the most popular responses were that they had established better records (24\% of all statements), greater staff specialisation (18\%) and strengthening internal controls (15\%).

\section{PUBLIC PROCUREMENT OVERSIGHT}

Public procurements today represent a significant portion of public finance expenditure, and stimulate economic activity. Legal remedies for tenderers are based on the principles of legality, speed, accessibility and effectiveness.

Audit procedures for public procurements are prescribed in the Auditing of Public Procurement Procedures Act. The act provides for legal remedies for tenderers in all phases of public procurement procedures and protection of the public interest in public procurement procedures.

Table 9: Public procurement oversight

\begin{tabular}{|l|c|c|c|}
\hline Were public procurement procedures subject to oversight & \multicolumn{2}{c|}{ Municipality type } & Total \\
\cline { 2 - 4 } from 2005 to 2008? & Urban municipalities & Other municipalities & \\
\hline Internal audit service & 5 & 22 & 27 \\
\hline Court of Auditors of the Republic of Slovenia & 3 & 11 & 14 \\
\hline Other & 1 & 10 & 11 \\
\hline Commercial auditing houses & 2 & 11 & 13 \\
\hline Budget Supervisory Office of the Republic of Slovenia & 0 & 3 & 3 \\
\hline Total & 11 & 57 & 68 \\
\hline
\end{tabular}

The most frequent supervisors were internal audit services (40\% of examinations), Court of Auditors (21\%) and commercial auditors (19\%). There was at least one form of oversight in 37 municipalities, while 3 municipalities listed 4 cases of oversight. From 2005 to 2008 public procurement procedures in the observed municipalities were subject to oversight in 68 cases.

\section{CONCLUSION}

The research project "Awarding Work to External Contractors" studied the practice of implementing public contracts in a significant selection of Slovenian local government bodies.

Public procurement has become a permanent accompaniment to the business of central and local government and other public law persons with the private sector, and now goes beyond Slovenia's borders. The public procurement system aims at dynamism, with the possibility of a rapid response to the needs of those using public funds. The principles of public procurement and its legal basis mean the system is rigid and complex, by its nature.

A total of 45 municipalities with over 8,000 inhabitants participated, representing over half of the entire Slovenian population. The observed municipalities are very diverse in terms of size, with the number of inhabitants ranging from just over 8,000 to 270,000 . This makes it unsurprising that the organisation and implementation of public procurement procedures differ significantly from municipality to municipality. The division of municipalities into urban and other reduced these differences slightly, but not entirely.

The number and value of public procurements is significantly higher in urban municipalities than in others ( 3 to 4 times depending on the category). The infrastructure for public procurement organisation is more developed 
in urban municipalities. They have special public procurement departments, involving more staff, and internal controls over public contracts are better. This means it is recommended, and for smaller municipalities almost essential, that municipalities combine forces in the organisation and implementation of public procurements (where possible). A joint service can be organised that will take responsibility for public procurement in all the associated municipalities. Part of the powers in this field will probably be assumed by regional levels of government in future. Nevertheless, the process of regionalisation in Slovenia is taking place relatively slowly. Public procurements are carried out on a daily basis, meaning inter-municipal cooperation in this field is highly recommended.

Despite this, the analysis of survey responses indicates that one cannot state that the larger municipalities all have better organised public procurement services. The students collecting data had problems and failed to acquired data from the largest municipalities (e.g. Koper, Maribor, Škofja Loka, and Žalec), as well as from smaller municipalities (e.g. Ivančna Gorica, Logatec, and Šentjur). They were most frequently refused on the grounds that the data would have to be collected specifically for the survey, which the responsible persons did not have time for. The fact is, however, that municipalities are required to submit all the numerical data for past years to the Ministry of Finance in statistical reports. Additional data collection would not be required, if their records were in order. At the same time, some municipalities responded quickly and affirmatively, and were also subsequently prepared to send 2008 data.

Those responsible for public procurement in municipalities have pointed out difficulties in the selection of the most favourable tenderer for public works. They consider in some cases that a monopoly or oligopoly of local organisations has effectively been created, which prevent the more economical spending of municipal budget funds.

Some people proposed the creation of independent, regional public procurement agencies that would ensure greater competition among potential providers, and bring together people with the necessary skills and experiences. The accessible data indicates that the Ministry of Finance aggregates and discloses total public contract values by year. It would clearly be possible to establish a system that, with detailed analysis and comparison of data, offered much more useful indications for the organisation of services, and implementation and oversight of public procurement. The publication of data would ensure the comparability of municipalities, and serve in preparing proposals for systemic improvements. The organisation of joint services for a group of municipalities would undoubtedly contribute to greater professionalism and effectiveness. The field of public procurement could be used as an argument against increasing the number of municipalities in Slovenia, since it leads to the creation of ever smaller municipalities. At the same time, the field could also serve as an example of best practice for formal or informal cooperation between municipalities within a regional tier of government.

Another major contribution could be made by standardising instructions on the selection of appropriate tenderers, since smaller municipalities in particular face major problems in implementing procedures. Public procurement is clearly an extremely demanding field for both contracting authorities and tenderers, and often demands an interdisciplinary approach. Although the field is complex, it would be possible to put a system of indicators in place that would serve the needs of every municipality. Comparing data available from municipal websites indicated that the data on public procurements is deficient.

Public procurements are most frequently mentioned in relation to successfully completed investments. One may only guess the reasons that local residents do not request more publicly accessible, online data on the volume and type of public procurements and their implementation. Public procurement requires specialised knowledge and the level of responsibility is relatively high. Some municipalities have already advertised to fill such positions without success. This has led to the practice in smaller municipalities of a large number of employees from various areas of administration working together to manage public procurements.

The knowledge required is gained through additional training. A frequent position was that there was a lack of training in this area, and it was not sufficiently specialised. In smaller municipalities there have been suggestions of introducing a system to transfer best practice on the organisation and implementation of public procurements. One can assume that the very small municipalities (those with fewer than 8,000 inhabitants), which have even smaller municipal administrations, face problems that are similar and even more acute. 


\section{AUTHOR INFORMATION}

Stanka Setnikar Cankar, Ph.D. obtained in 1993 the title of Doctor of Economics at the Faculty of Economics in Ljubljana. She is the author of many articles and books on public sector economics and editor-in-chief of the magazine "Uprava". She is a member of the NISPACee Steering Committee. She successfully heads various research projects in field of Public Sector Reform, Public Sector Economics (Tempus, Interreg, Leonardo da Vinci). From 2009 she carries out her function again as a Dean and is a member of Strategic Council of the Republic of Slovenia for regionalization.

Janko Seljak, Ph.D. was employed at the Statistical Office of the Republic of Slovenia. In years 1993 - 2003 he was teaching Statistics at the Faculty of Administration. Currently, he is independent researcher. He is the author of many books on statistics. He actively participated in projects in the field of balanced development, environmental protection, employment in the public sector, taxes, public procurement and competency models in public sector management. Less but not least he participated in projects in the field of healthcare economics and complementary treatment methods.

Veronika Petkovšek graduated at the Faculty of Economics in Ljubljana in 2008. In 2008 she was employed at the Faculty of Administration as an assistant in the Department of Public Sector Economics. Her areas of research interest encompass Public Sector Economics in Slovenia in the field of changes in the healthcare system, public procurement and measuring the efficiency and effectiveness of public sector. She also participates at the international research projects, such as Interreg and Leonardo da Vinci.

\section{LITERATURE AND SOURCES}

1. Gregorič, Mojca: Javna naročila ter možnost njihovega vpliva na okolje. Master's dissertation. Ljubljana: Faculty of Adminstration, 2008.

2. Kranjc, Vesna: Zakon o javnih naročilih (ZJN-1) s komentarjem. GV Založba, Ljubljana, 2001.

3. Kranjc, Vesna: Zakon o javnih naročilih s komentarjem, GV Založba, Ljubljana, 2004a.

4. Kranjc, Vesna: Zakon o javnih naročilih z novelo ZJN-1A: Uvodna pojasnila dr. Vesna Kranjc. Ljubljana: GV Založba, 2004. p. 186.

5. Kranjc, Vesna: Novi postopki javnega naročanja: Revija za javna naročila in javne finance, Inštitut za lokalno samoupravo in javna naročila, Maribor, May 2006.

6. Kranjc, Vesna: Formalnost v postopkih javnega naročanja, zakaj strogost in kdaj popustljivost. Dnevi slovenskih pravnikov 2006. Ljubljana GV Založba, 32 (2006a), 6/7, pp. 1436-1443.

7. Korpič-Horvat Etelka: Revizijski postopek oddaje javnih naročil. Pravna praksa, Ljubljana, 1997, p. 1, p.7.

8. Lipec, Marija: Javna naročila malih vrednosti. Degree dissertation. Ljubljana: Faculty of Administration, 2007.

9. Ministrstvo za finance. 2009. Podatki občin o realiziranih prihodkih in drugih prejemkih ter odhodkih in drugih izdatkih splošnega dela proračuna ter o realiziranih odhodkih in drugih izdatkih posebnega dela proračuna, Ljubljana: Ministrstvo za finance, http://www.mf.gov.si/slov/fin_loksk/obrazec_P_P1/EK-2007vsi-KONCNI.xls

10. Mužina, Aleksej and Pirnat, Rajko: Zakon o javnem naročanju (ZJN-2) in Zakon o javnem naročanju na vodnem, energetskem, transportnem področju in področju poštnih storitev (ZJNVETPS). Nebra, d.o.o., Ljubljana, 2007.

11. Mužina, Aleksij and Vesel Tomaž: Zakon o javnem naročanju (ZJN-2) in Zakon o javnem naročanju na vodnem, energetskem, transportnem področju in področju poštnih storitev (ZJNVETPS) s pojasnili členov, pravom EU ter pravno prakso. Nebra, Ljubljana, 2007.

12. Pivk Tanja: Problematika javnih naročil v javnem sektorju. Specialistično delo. Ljubljana: Faculty of economics, 2006.

13. Planet GV, poslovno izobraževanje, d.o.o.. Kako korektno in uspešno pripraviti javna naročila. $\mathrm{URL}=\ll$ http://www.planetgv.si/index.php?page=event\&eid=2639«.22.3.2009.

14. Setnikar Cankar et. al., Ekonomika javnega sektorja s proračunskim financiranjem. Faculty of Administration, Ljubljana, 2008. 
15. Smrdel, Borut: Vpliv odločitev državne revizijske komisije na spreminjanje dosedanje prakse pri oddaji javnih naročil malih vrednosti. 11. posvet Dnevi javnih naročil. Portorož, 2008.

16. Šltes, Igor: Prikaz pravne ureditve javnih naročil v Sloveniji in mednarodne primerjave skozi zgodovinski pregled. In: Ferfila B. (ed.): Ekonomski vidiki javnega sektorja. Faculty of Social Sciences, Ljubljana, 2007, pp. 558-639.

17. Zakon o javnem naročanju. Official Gazette of the Republic of Slovenia, nos 128/06, 16/08.

18. Zakon o javnem naročanju na vodnem, energetskem, transportnem področju in področju poštnih storitev. Official Gazette of the Republic of Slovenia, no 128/06, 16/08. 
NOTES 